\title{
AN INVESTIGATION INTO USING SUPPLEMENTARY MATERIALS IN TEACHING ENGLISH SPEAKING SKILLS AT HIGH SCHOOL
}

\author{
Nguyen Thi Thu Hoai ${ }^{1 *}$, Nguyen Thi Hoa ${ }^{2}$ \\ ${ }^{I} T N U$ - School of Foreign Languages \\ ${ }^{2}$ TNU-International School
}

\begin{abstract}
Nowadays the use of teaching materials in English lessons becomes more necessary and popular. The benefits of using supplementary materials have improved teaching and learning English. Since the beginning of language studies, Second and Foreign Language Acquisition researchers have been searching for effective methods to improving learners' language skills. This study aimed at investigating the use of supplementary sources on teaching speaking skills. Quantitative method is chosen in this research by using the survey for teachers and students. Results of the study demonstrate on the situation of supplementary materials in teaching process, the frequency use of these materials and the effectiveness of materials in organizing activities as well as suggest some solutions to enhance teaching speaking outcomes.
\end{abstract}

Keywords: Supplementary materials; teaching materials; speaking skills; teachers; teaching practice

Received: 25/5/2020; Revised: 19/6/2020; Published: 22/6/2020

\section{NGHIÊN CỨU SỬ DỤNG TÀI LIỆ BỔ TRỢ TRONG DẠY KỸ NĂNG NÓI TIẾNG ANH TẠI TRƯờnG TRUNG HỌC PHỔ THÔNG}

\author{
Nguyễn Thị Thu Hoài ${ }^{*}$, Nguyễn Thị Hoa ${ }^{2}$ \\ ${ }^{1}$ Khoa Ngoại ngũ - ĐH Thái Nguyên \\ ${ }^{2}$ Khoa Quốc tế - ĐH Thái Nguyên
}

\section{TÓM TẮT}

Ngày nay việc sử dụng tài liệu bổ trợ tiếng Anh trong giảng dạy đã trở nên cần thiết và phổ biến hơn. Lợi ích của sử dung tài liệu đã góp phần nâng cao hiệu quả dạy và học tiếng Anh. Từ các nghiên cứu đầu tiên về ngôn ngữ, các nhà nghiên cứu về tiếp nhận ngôn ngữ thứ hai và tiếp nhận tiểng nước ngoài đã tìm các cách dạy học hiệu quả nhằm nâng cao kĩ năng ngôn ngữ của người học. Nghiên cứu này với mục đích điều tra việc sử dụng tài liệu hỗ trợ trong giảng dạy kỹ năng nói tiếng Anh. Phương pháp nghiên cứu định lượng được lựa chọn và áp dụng trong nghiên cứu, phiếu khảo sát dùng cho giáo viên và học sinh. Kết quả nghiên cứu tập trung vào thực trạng sử dụng tài liệu bổ trợ, mức độ thường xuyên sử dụng tài liệu và hiệu quả của việc sử dụng tài liệu hỗ trợ trong giảng dạy và đề xuất một số giải pháp nâng cao chất lượng dạy kỹ năng nói tiếng Anh.

Từ khóa: Tài liệu bổ trọ; tài liệu giảng dạy; kỹ năng nói; giáo viên; thực hành giảng dạy.

Ngày nhận bài: 25/5/2020; Ngày hoàn thiện: 19/6/2020; Ngày đăng: 22/6/2020

* Corresponding author. Email: tnhoai.sfl@tnu.edu.vn

DOI: https://doi.org/10.34238/tnu-jst.3186 


\section{Introduction}

For many years, teaching English as a foreign language has played important roles in the development of society. Teachers try their best to find effective approaches of teaching English in different conditions. To achieve success within the teaching and learning process, teaching materials are an important part because teachers need rely on a diverse range of aids that can support students' learning and reach teaching objectives. One of these aids is the use of supplementary materials that becomes an advantage for teachers if the materials are properly used, they will work effectively at the moment of imparting classes to the learners.

According to [1], the use of supplementary materials has many advantages for foreign language (EFL) teachers and students in improving vocabulary and speaking skills. By using the materials, learners can enrich vocabulary easily, EFL teachers have the benefit of teaching vocabulary through context. In addition, researchers have studied the impact of visual and verbal clues on learning words in context. In this regard, Walters [2] reported that the results of reading comprehension were improved in the study of 11 ESL students (ranging in age from 17 to 47), enrolled in an English language program which were applied the strategies of how to derive meanings of unfamiliar words from context of reading materials in class and at home.

Supplementary materials are considered as a promising tool for language learning purposes. Scholars in the field have proposed various advantages for the use of source in English as a second or foreign language (ESL/EFL) classes. Stern believes that supplementary materials offer potential benefits of a high order for ESL/EFL. Linguistically, they can help students master the vocabulary and grammar of the language as well as activate the four language skills: reading, writing, listening, and speaking [3].
It is worth mentioning that supplementary materials can be used to improve many subskills in reading. Learners must be persuaded to predict what is going to occur by reading the title, the first paragraph and to induce what the passage will be about. Then, learners should be able to defend their imaginations with proofs from the text and the possible impact it may have on the reading performance of the passages [4]. According to [1], series regarding the passages and the short stories for the purpose of improving reading skills are all on the line of the same purposes and objectives.

Results of some previous studies have been done to demonstrate the use of supplementary materials and the influences on teaching and learning process. For example, the study of Kelsen [5] aims to explore the use of YouTube as supplementary material with EFL students in Taiwan. Its limitations were that the questionnaires were only written in English, the self-reported nature of the survey may have led to students overstating their answers, the relative sample size was small, and all of the participants came from the same department. It meant that the results could not be extrapolated to the general student population. Another study made by Peacock [6] was to explore whether authentic materials increase the classroom motivation of learners, a claim often made, but rarely, if ever tested, which had as a limitation the generalizability of the results is limited by the small scale of the study and the level of the learners, who were all beginners. Finally, the study [7] was done to examine the effects of treating learners in a classroom to digital visual materials on a shared display, while interleaving such materials with scanned copies of relevant textbook pages, with no limitations identified.

Using supplementary materials will create more interesting activities if the material is correctly selected in planning the lessons. When teachers choose one kind of material to 
use in each lesson, it is very important to consider its pertinence and appropriateness in order to achieve the proposed goals. Teachers decide to choose a great variety of supplementary materials such as visual, audio, audiovisual, online and others; however, just some teachers are using them regularly. Therefore, it is necessary to investigate the situation of using supplementary materials in teaching English, especially speaking skills at high schools. The purpose of this study is to survey the application of supplementary materials in teaching process, the frequency use of these materials and the effectiveness of materials in organizing activities.

\section{Methodology}

\subsection{Research questions}

1. How often do teachers apply supplementary materials in teaching speaking?

2. What are teachers' opinions about supplementary materials used in speaking activities?

3. What are learners' reflections about supplementary materials?

\subsection{Participants}

The first group of participant in this study consisted of 10 English teachers at Tran Quoc Tuan and Dao Duy Tu high schools in Thai Nguyen. The second group was students who studied at high schools in grade 10 and grade 11 (200 students).

\subsection{Data collection instrument}

The questionnaires were used as the main data collection instrument for the study. In the study, the questionnaires were designed for teachers and students. They concentrated on the kinds of supplementary materials in teaching practice; the frequency of using supplementary materials; effective materials used in teaching English and learners' reflection about supplementary materials. The questionnaires were designed following Likert scales with four responses. Each of them would have a numerical value which would be used to measure frequency and agreement.

\subsection{Data analysis}

Data of the questionnaires were converted into statics, numbers and percentage in the form of tables and charts for the purpose of comparison and analysis. The kinds of materials, the frequency of using materials and effectiveness of materials in teaching were calculated for comparison and contrast by using Google drive and Excel.

\subsection{Data collection procedure}

Initially, the questionnaire was delivered to teachers to see the situation of using supplementary materials in teaching English. The second questionnaire was sent to learners at the same time of teachers in order to collect information about learners' reflection. All the data was collected to synthesize and analyze.

\section{Findings and discussion}

\subsection{Findings}

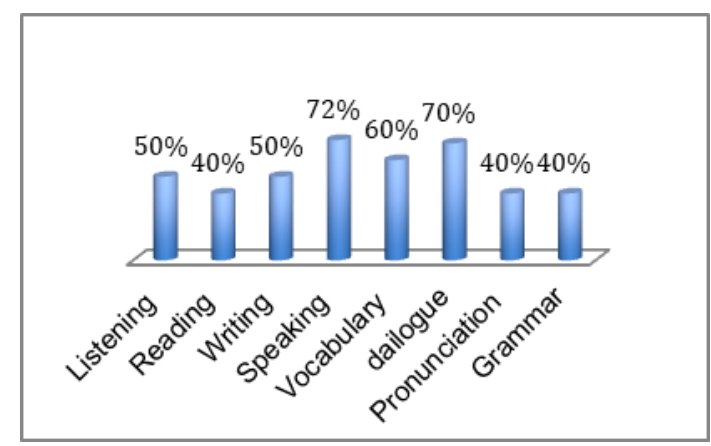

Figure 1. Materials used in teaching

As can be seen from the Figure 1, when teaching speaking, teachers used variety kinds of supplementary materials for speaking activities and dialogue with $72 \%$, $70 \%$ respectively of materials in class while there were $40 \%$ of materials used in reading, pronunciation and grammar lessons. 50\% of supplementary materials were applied in both writing and listening activities. Teachers used $60 \%$ of materials in teaching vocabulary in order to have better outcomes in teaching and learning. 


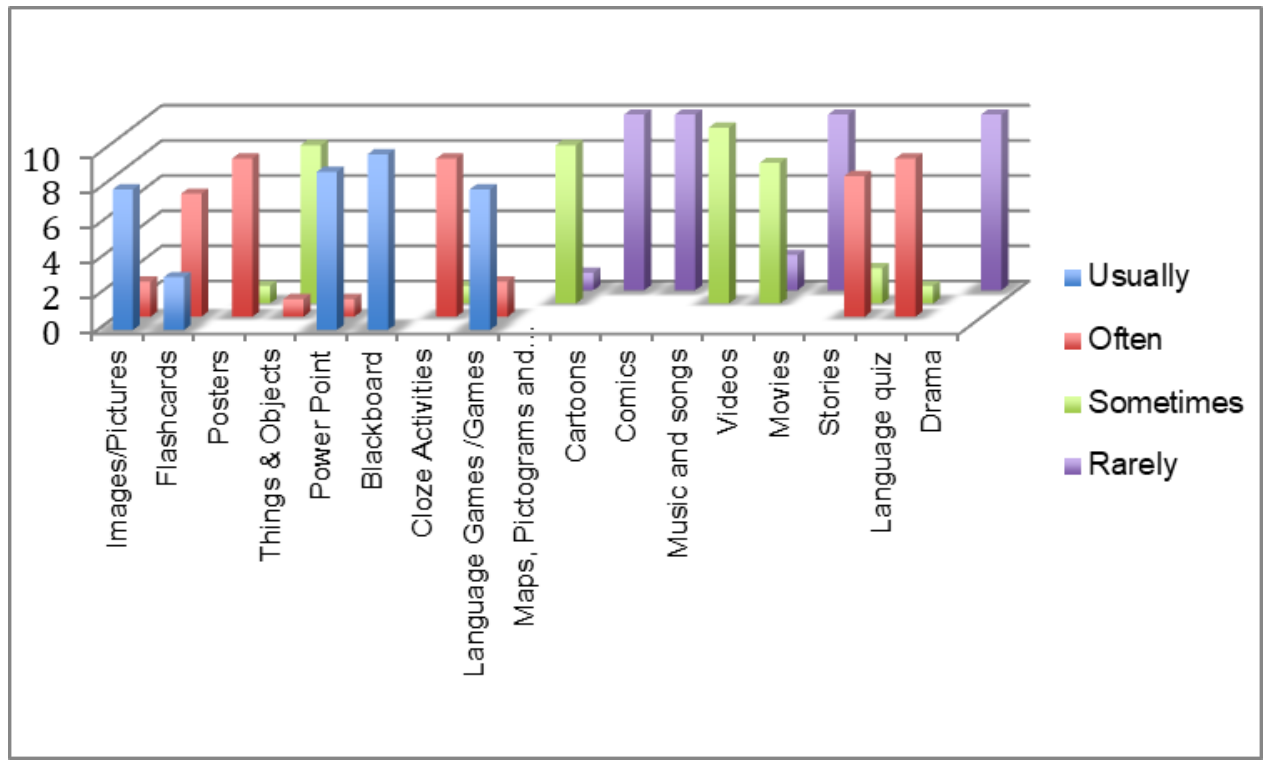

Figure 2. Frequency of using the materials for speaking activities

Figure 2 shows that pictures, images, power point, blackboard and games were used regularly in all speaking activities in class. The second popular materials were chosen by teachers including flashcards, posters, cloze activities, stories and language quiz. Teachers often used these materials in teaching speaking skills. In addition, teachers sometimes chose things, objects, maps, pictograms, graphs, music, songs and videos in teaching speaking. It is noticeable to see that teachers rarely used cartoons, comics, movies and drama as supplementary materials.

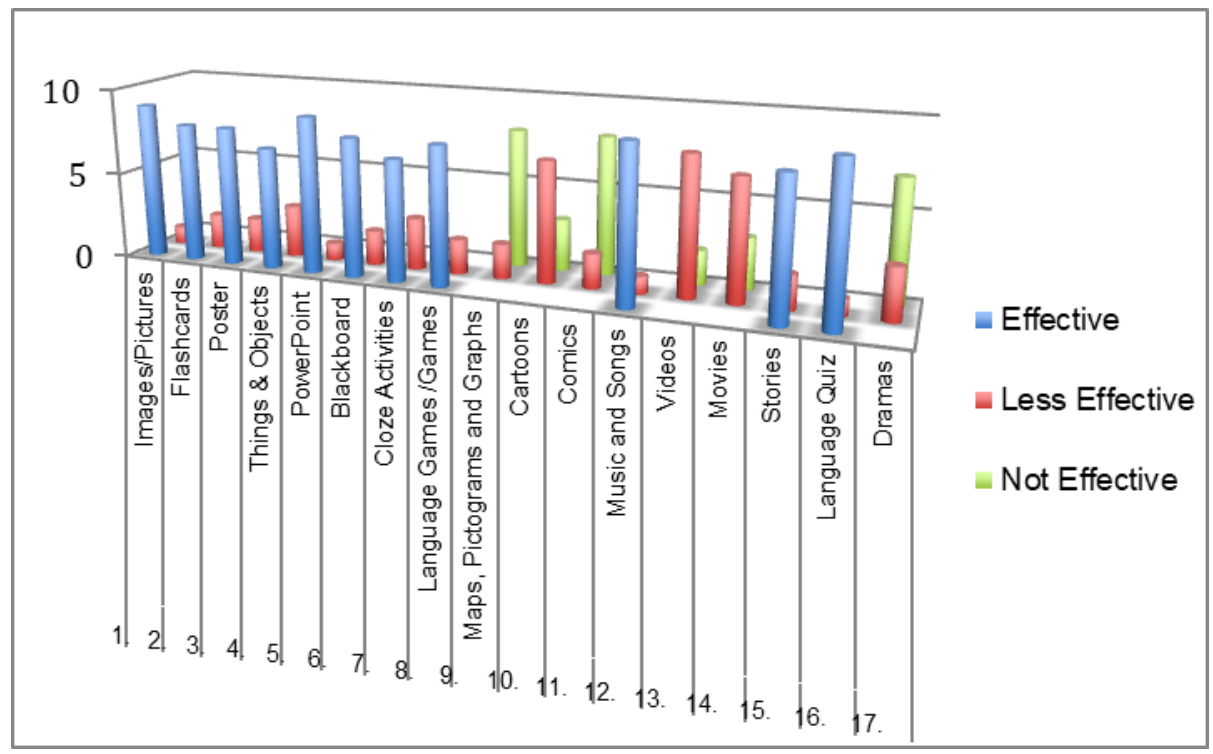

Figure 3. Teachers' perspective about the effectiveness of materials

As can be seen from Figure 3, teachers pointed out their perspective about the effectiveness of supplementary materials in speaking activities. Most kinds of materials (11/17 materials) were highly appreciated in teaching because they could bring effectiveness for learners. There were three materials belong to less effective group. During the time of teaching, teachers found that maps, pictograms, graphs, comics and dramas were not effective in organize activities. 


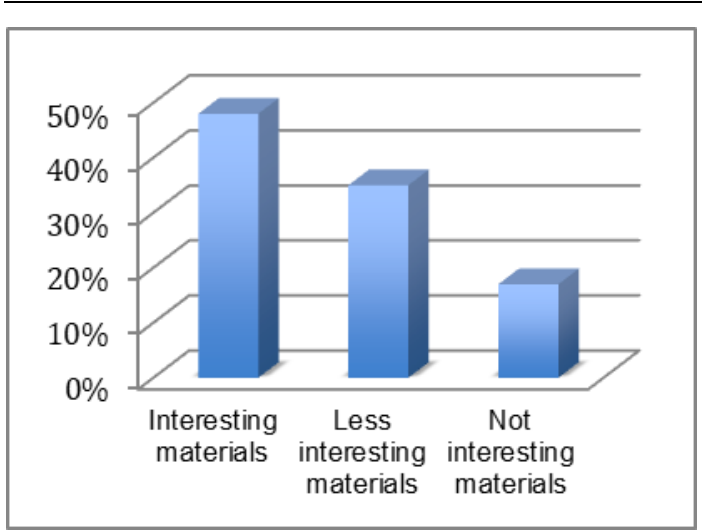

Figure 4. Leaners' reflection about supplementary materials

It can be seen in the Figure 4 that students felt delighted and motivated when learning with supplementary materials prepared by teachers in each lesson. Students chose $50 \%$ of those materials in interesting group and defined one third of all materials for the less interesting materials $(35 \%)$. The rest of the materials were reflected to be uninteresting.

\subsection{Discussion}

The purpose of this study was to explore the real life situations in using supplementary materials during the time of teaching speaking and the effectiveness of using supplementary materials on learning English. Teachers applied many kinds of supplementary materials in each English period. The findings indicated that using variety kinds of supplementary materials is effective in improving learning outcomes. Learners felt excited and were motivated in taking part in speaking tasks. Both students and teachers reflected that using visual aids, games, music and power point were effective in teaching.

Activities attracted learners by using variety kinds of materials in learning English; therefore, they would not feel bored during the lessons. It was clear that applying supplementary materials in teaching would lead to greater concentration for learners in learning.

With the chosen materials, teachers were not the sole presenters of materials, learners would take cooperative attitude in learning. As a result, the classroom would be a friendly atmosphere where optimal learning occurs. Deployment of supplementary materials brings more benefits for teachers and students in teaching and learning English.

\section{Conclusion and Recommendations}

\subsection{Conclusion}

As mentioned, this study aimed to survey the situation of applying supplementary materials including kinds of materials, frequency use of materials in English periods, perspective of teachers and learners about effectiveness of these materials in teaching and learning English speaking skills. The results of the study can illustrate that applying and designing supplementary materials in language teaching can be effective in teaching practice at high school. Taking advantages of such supplementary sources will promote students' motivation and students' interest inside classroom and outside classroom participation.

\subsection{Recommendations}

- Teachers should spend more time on using supplementary materials such as comics, movies, blackboard or stories in terms of designing activities inside classroom as well as outside classroom.

- When designing English activities, teachers should care about learners' needs, learners' knowledge and content of the lessons in order to choose appropriate materials and organize activities effectively.

- Teachers should ask students to give feedbacks for the use of supplementary materials, therefore, they can change the kinds of materials for the following tasks because there are differences between teachers' perspective and learners' feedback about the effectiveness of supplementary materials.

- When planning and designing materials in each lesson, teachers should discuss with 
colleagues or instructors to receive useful feedbacks before teaching.

- Since the technology is in progress everyday, it is necessary for teachers to update online supplementary materials in teaching. Consequently, students will have more chance to use these sources at school and at home. For achieving this goal, the institutions should implement courses or seminaries about the new sources that exists on websites to use in the classroom.

- Things and objects should be used frequently in speaking tasks in order to raise interest and curiosity of the students and make the lessons more interesting and motivating.

\section{REFERENCES}

[1]. G. Chwo, A. Jonas, C. Tsai and C. Chuang, "Adopting supplementary material to enhance listening and speaking strategy used by Taiwanese college EFL learners," 2010. [Online]. Available: http://gas.hk.edu.tw/main/download/journal/5 9/25-41.pdf. [Accessed May 11, 2019].
[2]. J. Walters, "Methods of teaching inferring meaning from context," Regional Language Centre Journal, vol. 37, no.2, pp.176-190, 2006.

[3]. S. L. Stern, "An Integrated Approach to Literature in ESL/EFL," in Teaching English as a Second or Foreign Language, M. CelceMurcia Ed. Heinle \& Heinle, 2001, pp.328-329.

[4]. Y. M. Goodman and A. B. Carolyn, Reading Miscue Inventory Manual Procedure For Diagnosis And Evaluation, New York: Macmillan Publishing, 2007.

[5]. B. Kelsen, "Teaching EFL to the iGeneration: A survey of using YouTube as supplementary material with college EFL students in Taiwan," CALL-EJ Online, New York: Macmillan Publishing, vol.10, no.2, pp.1-18, 2009.

[6]. M. Peacock, "The effect of authentic materials on the motivation of EFL learners," ELT Journal, vol. 51, pp.144-156, 1997.

[7]. S. Panjwani, L. Micallef, K. Fenech and K. Toyama, "Effects of integrating digital visual materials with textbook scans in the classroom," International Journal of Education and Development using ICT, vol.5, no.3, pp. 55-71, 2009. [Online]. Available: https://www.learntechlib.org/p/42284, 2009. [Accessed May 10, 2019]. 